\title{
移動視標の方向変化に対する反応時間
}

\author{
河辺章子 (奈良女子大学) \\ 大 築 立 志(奈良女子大学)
}

（昭和54年 2 月 19 日 受付）

\section{Reaction Time to the Directional Reversal of the Moving Object}

\author{
Shoko Kawabe* \\ Tatsuyuki Ohtsuki*
}

\begin{abstract}
The purpose of present study was to investigate the reaction to the horizontally moving object with special reference to the mechanisms of anticipation. The reaction time was measured by using the stimuli which were directional reversal of the moving object. The stimulus was provided successively and periodically in order to establish anticipation to stimulus presentation. Stop of motion or deceleration was inserted occasionally between directional reversal to break anticipation.

Ten normal adult female university students served as subjects. The subject was asked to respond to the stimulus by pushing the conventional telegraph key. The action potentials of forearm flexors and extensors were ledoff by biolpar surface electrodes. Horizontal eye movement was recorded by Electro-Oculography.

The results obtained were summarized as follows :

1) As the degree of anticipation to the directional reversal became higher by periodic stimuli, reaction with negligible latency appeared. On that occasion, stopping the motion or reducing velocity, error reaction occured. This means that motor output was provided independently of sensory input.

2) Of the possible two kinds of anticipation of timing point, temporal anticipation plays a more important role than spacial one.

3) Reaction time with the moving object was shorter than with flash of light.

4) The eye movement, which was in most cases saccadic with the target velocity employed in the present study, was also influenced by anticipation. As anticipation became established, eyes saccadicly moved in advance of target to the position where the stimulus will be presented, and stayed there waiting the stimulus presentation.
\end{abstract}

* Nara Women's University, Kitawoyanishi-machi, Nara (630) 
It suggests that there exists the mechanism which enables quick reception of the information about the changes of the external world.

(Shoko Kawabe, Tatsuyuki Ohtsuki : Reaction Time to the Directional Reversal of the Moving Object. Jap. J. Phys. Educ., Vol. 24, No. 4, March, pp. 301 311)

\section{I . 粕}

反応時間に関する研究は, 19世紀以来様々な力 法を用いて，数多く行なわれてきた。特に，視覚 を介しての反応時間を測定する際には，固定光を 刺激として行な5 あのが注とんどであった。

しかしながら，実際のスポーツ場面において は，視対象は時々刻々と移動しており，視対象の 「動きの変化」を刺激として反応が行なわれる場 合も多い，例えば，ボールゲーム等の対人場面の 成立するスポーツにおいては，プレイヤーはボー ルや相手プレイヤーの運動方向や速度の変化を刺 激として反応動作を行ならことが多いと考えられ る.

「動き」に着目した反応時間の研究としては，堀

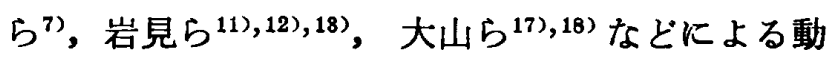
体視反応時間の研究があるが，これらはいずれも 移動する光点の点隇や輝度变化を刺激としたもの であって，純粋な「動き」又は「動きの変化」を 刺激とした反応時間を报ったすのではない，「動 きの変化」とい5入力刺激の情報処理と, 固定さ れた視対象の状態変化に関する情報処理とに差が あるのかどうかは興味ある問題であるが，この点 に関する詳しい研究はなされていない。

またこのような「動きの変化」に対しては, その変化を入力刺激として，「反応時間」分の遅 れを伴った，いわゆる古典的な反応動作を行な5 場合の他に，できるだけ「タイミングの合った」， すなわち，「反応時間」がゼロであるような動作 や，刺激に先行した，相手の機先を制すよ5な動 作を行ならことが必要とされる場合も多い。

このタイミングとい5点に着目して，山田らは タイミングコントロールに関する一連の研究を行 ない，動作における予测の重要性を指摘している 23),24),25),26),27)，つまり，「タイミングを合わせる」 といらことは，相手の動きを予測して（読んで） 反応することであり，予測が適確であれば，無理
なく無䭾のない動きができ，自分の立場を有利に 導くことができる。

しかし，一力ではタイミングを合わせた結 果, 極めて不利な状況に追い込まれる場合があ る. いわゆるフェイントにかかった場合がその例 である，逆の立場から言党ば，自分の動きを相手 に予测させて，それを5まくはずす，つまり，

「タイミングをはずす」ことによって，有利な態 勢をつくることができるということもまた多く経 験されることである。

いずれにせよ，「動きの変化」に対する反応に は，予测とい5因子が密接に関連しているものと 思われる。

本研究は，移動視標を用いて「動きの変化」を 刺激とする反忘時間を測定し，しかも，刺激呈示 に周期性をむたせて予測状態をつくることによっ て，動きに対する反応特性を研究すると共に，そ の予測との関連についての考察を行な5ことを目 的とするものである.

$$
\text { II. 方法 }
$$

\section{<実験 I >}

1. 装置四 1 のように, 直径 $4.5 \mathrm{~mm}$ の緑色ランプ

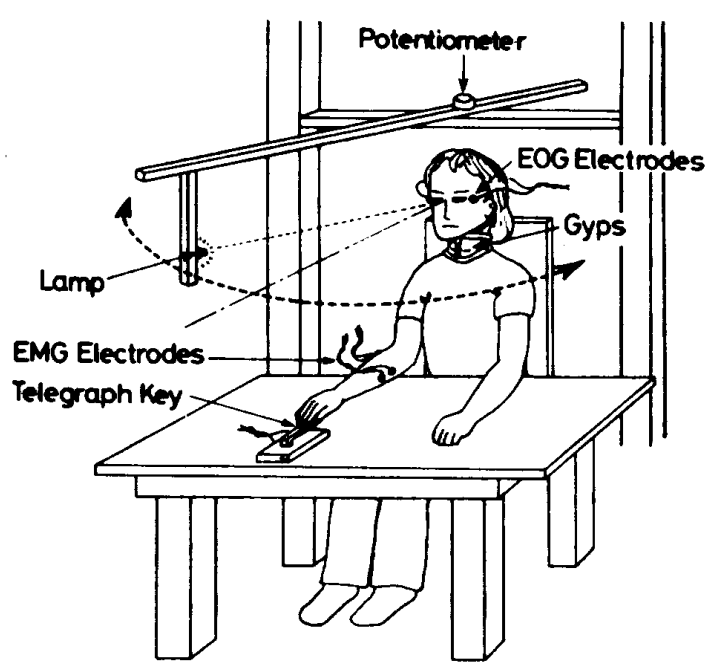

図 1 実験装置 
を視標とし，被検者の頭頂を中心に円弧を描いて 水平面上を移動させた。被検者との距離は $80 \mathrm{~cm}$, 高さは目の位置に合わせた。移動方法は検者によ る手動で行ない，その動きを potentiometer によ って記録した。な打，移動平均速度は $83.8^{\circ}$ /秒で 各セット，被検者間でもほぼ等しかった。

反忘として，視標の動きの変化に対し，机上の 電鍵（KE-I 型）を押す動作を行なわせ，指屈筋 及び指伸筋から表面電極法により筋電图を導出し た。また，両眼窩外側縁にゴムキャップ型銀盤電 極を装着し,EOG 法により眼球運動を記録した。 测定の際に，頭部や体の動きによって発生する眼 球反射が混入しないように被検者の体幹を椅子 に，頭部をギプスによって固定した。

記録はすべて日本光電社製ポリグラフ RM85型 により,ペーパー速度 $10 \mathrm{~cm} /$ 秒で行なった。

2 . 被検者

健康な成人女子 5 名（平均年令 21.4 才）

3 . 実験手続き

刺影条件として，次の 4 種類を設定した。

1) 移動開始条件…被検者の正面に停止してい る視標が動き始めることを刺激とし，右へ動き始 めたら右手，左へ動き始めたら左手で反応する。 これは，方向変化に対する反応が停止からの動き の開始を刺激としているかどらかを見るために設 けた条件である。

2) 単純方向変化条件…移動途中の視標がその 移動方向を変えることを刺激とする，例えば，右 へ動いている視標が移動方向を左へ変えることを 刺激として右手で反応し，左から右への変化に対 しては，左手で反応する．方向変化位置はランダ ムとした，本条件のみ被検者は 4 名である。

条件 1) 及び 2) では刺激呈示間隔を $1-15$ 秒 としてランダムに与え，22試行からなるセットを 左右別に 1 セットずつ行なった.

3 ) 連続方向変化条件...視標の移動方向が右左 右左と規則的に変化し，その方向変化を刺激とす る. 条件 2) と同じく，右から左への変化に対し ては右手で反応を行な5．条件2，，3）共に方向 変化を刺激とする点では同じであるが，条件 3 ） では刺激を連続的にしかも規則的に与えることに より，予测との関連をみることを目的としてい
る. 方向変化位置はランダムとし，刺激呈示間隔 は0.5一1秒の間で与えた。

この条件 3 ）飞おいて，方向変化と方向変化の 間に視標が停止するという場合を設けた。この停 止を「予測崩罗刺激」と呼び, 方向変化とい5 「通常刺敨」と区別する。そして，停止に対して 生じる反応を誤反応とした．方向変化が完了した 場合のみを試行と呼ふこととし，開始前の停止期 も含めて，停止と停止の間には少くとも5 試行を 入れるよ5にし，その後 $1-8$ をランダム化した 試行直前に停止を挿入した。たたし，最後の停止 から終了までは，常に 5 試行を与えることとし た（1セットの例…RLRLRLRL(SLRLRLR(SL RLR…：(Sは停止） 1 セット中に 5 回の停止を扱 入したので, 1 セットの試行数は30-65試行の範 用にある。セット間に 1 分間の休㲘をはさんで, 停止捜入 6 セット，無捜入 2 セットをランダム順 に行なった。

4 ) 固定光刺激条件 $\cdots$ 固定されたランプの点灯 を刺激とする. 本条件は 1) 及び 2) と同様の手 続きで行なった（左ランプの点灯に対しては左 手，右ランプには右手で反忘する). 条件 1) 一 3 ）は動きの変化を刺激とするもので，条件 4) はこれとの比較のために設けたものである・ま た，条件 1)，2），4）はいわゆる単純反応であ り，条件 3 ）は左右の選択反応である.

被検者を椅子に固定し，前腕を机上にのせて電 鍵に指をかけ，リラックスして刺激呈示を待つよ 5に指示した。条件 1) では「ランプが動き始め たら」，条件 2）では「ランプの移動方向が変わ ったら」, 条件 3 )では「ランプの移動方向が左か ら右へ変わったら左手で, 右から左へ変わったら 右手で」，条件 4 ）では，「ランプがついたら」, いずれも「できるだけ早く電鍵を押す」よ5に教 示した。各条件の第 1 セット開始前に数回の練習 を与え，要領を得させた。なお，室内は背景がか ろうじて識別できる程度の明るさにした。

\section{4. 記録処理について}

刺激呈示から指届筋の放電開始までを筋放電開 始時間 (以下ETと略す), 電鍵が ONになるまで を動作時間 (以下 MT と略す), 筋放電開始から 電鍵が ON になるまでを筋収縮時間 (MT-ET, 
以下 CTと略す) として、いわゆる反応時間（Reaction Time)における 3 つの時間相を湘定した。 なお，CT は筋収縮開始から電鍵のバネの力が克 服されて、レバーが移動し，スイッチがはいるま での時間を含んでいるが，便宜上，筋収樎時間と 呼ぶことにする。

なお，条件 4）における ET に左右差はみられ なかったので，本研究では左右はこみにして平均 值を表示することとした。

3）の連続方向変化条件での眼球 運 動におい て, 刺激呈示直前に発生する，視標の移動方向へ の最後の saccade 開始から刺激呈示までの時間を 眼球待機時間 (Eye Standby Time, 以下EST と 略す）と定義した。

\section{<実験 II >}

後述するような理由により，追加実験として実 験 II を行なった。

1 . 被検者

健康な成人女子 5 名（平均年令 20.8 才）

\section{2 ・装置及び手続さ}

実験 I と同様であるが，条件 3 ）における方向 変化位置をランダムではなく左右 $40^{\circ}$ の定位 置 と し，刺激呈示間隔を約 1 秒として刺激を与えた。

また，予測崩㐭刺激として，実験 I と同じ停止 の他に，移動速度を急に低下させて刺邀呈示間隔 を長くするとい5周期性を乱す刺激を新たに加え た。

さらに，2）の単純方向変化条件についても， 条件 3 ）と対応させるために，方向変化位置を左 右それぞれ $20^{\circ}, 40^{\circ}, 60^{\circ}$ とし，この 3 種類の位固 がランダムに与光られるようにして，40での測 定值のみを分析に用いた。

なお，反応は各条件とす右手のみで行ない，室 内は背景が見えない程度の暗さであった。

\section{III. 結 果}

1 . 反応時間 (ET, MT, CT) について

(1) 実験 I の連続方向変化条件に和ける反応時間

図2に1セット内の ET, MT, CT の変動の一 例を示した． $は$ は予測崩壊刺激（停止）を表わ す. 予測崩壤刺激後の試行 26-33では，始めは ET $157 \mathrm{msec}, \mathrm{MT} 231 \mathrm{msec}$ であったが，しだ

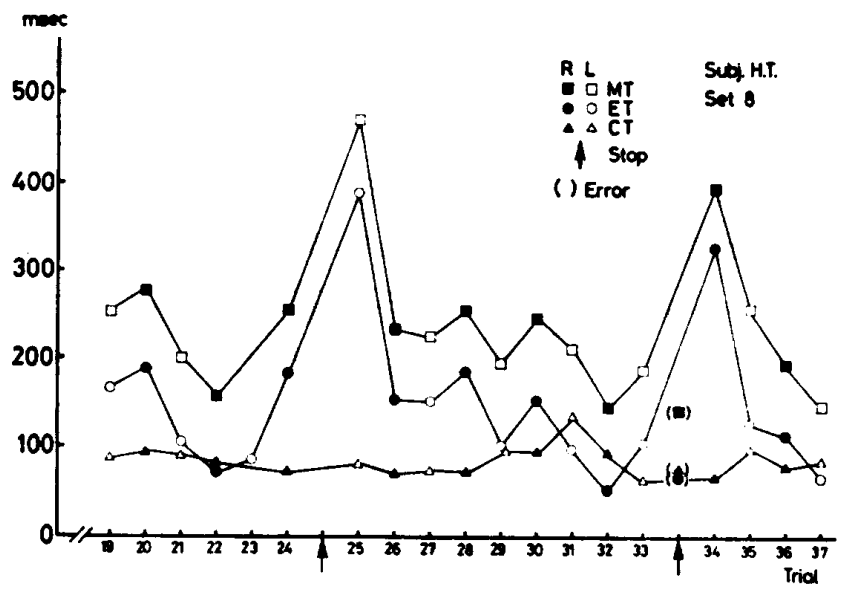

図 2 实駼 Iにおける ET, MT, CT の一般的傾向

いに減少し，ETでは生理的限界とされている100 $\mathrm{msec}^{9)}$ を下回る值す出現している. 同じく停止 （斉には示されていない）後の試行 1S一23におい ても，同様の傾向がみられる。

CT は汪とんど変化せず，100 $\mathrm{msec}$ 前後で一定 值を保っている。

停止を挿入すると，試行33と34の間にある（） の值のよ5に，本来反応すべきではないのに反応 を起こす場合がすべての被検者においてみられ た. その出現頪度は全停止数の 33\%であった. 停 止時点からの誤反応（右）の潜時をとると，本例 (ET 68msec) の如く, 試行32 (ET 51msec) と 近似した小さい值を示す傾向がみられる，停止直 後の試行（試行25及び35）では，予測の崩塄によ って見極め的反応となるためか，反応時間に極度 の遅延がみられ，いずれもETで 300 $\mathrm{msec}$ を越え る值を示した。しかし，その遅延すすぐに消失 し, 陚行が進むにつれて再び減少していくことが わかる。

(2) 実験 I の各条件における反応時間とその比較 被検者 5 名の各条件に打ける平均值を図 3 に示 した３）の連続方向変化条件での平均値は，予 測崩壊刺激に対する反応とその直後の反忘の值を 除いて算出したものである.

条件 1，，2，3）之も，3つの時間相について ほぼ等しい值を示しETでは $120 \mathrm{msec}$ 前後, MTで は $220 \mathrm{msec}$ 前後, CT では $90 \mathrm{msec}$ 前後であった。

条件 4) では，1，2，3）に比へてET，MT と もに延長しET約 $180 \mathrm{msec}, \mathrm{MT}$ 約 $270 \mathrm{msec}$ であっ 


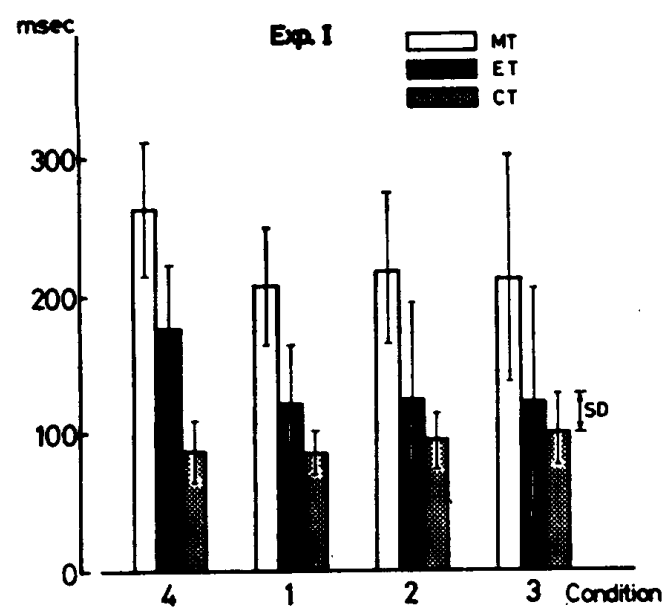

図 3 実験 I K拈ける各条件下での平均值

たが，CTは 1),2),3）同様，活ぼ90msec であっ た. 従って, 反応時間の条件間における差は ET によるものであることがわかる。

ET の平均值について，刺激条件，反忘方向 (右, 左), 被検者を因子としてF検定 ${ }^{10)}$ を行なっ た結果, 刺激条件のみ有意であり $\left(F_{(3,9)}=6.433\right.$, $\mathrm{p}<$.05), 特に 1),2）,3）の動きの変化を刺激之 する条件と 4）の固定光刺徹条件との間に有意な 差がみられた。

しかし，2）の単純方向変化条件では, ET123.2 $\mathrm{msec}, 3)$ の連続万向変化条件では ET $121.8 \mathrm{msec}$

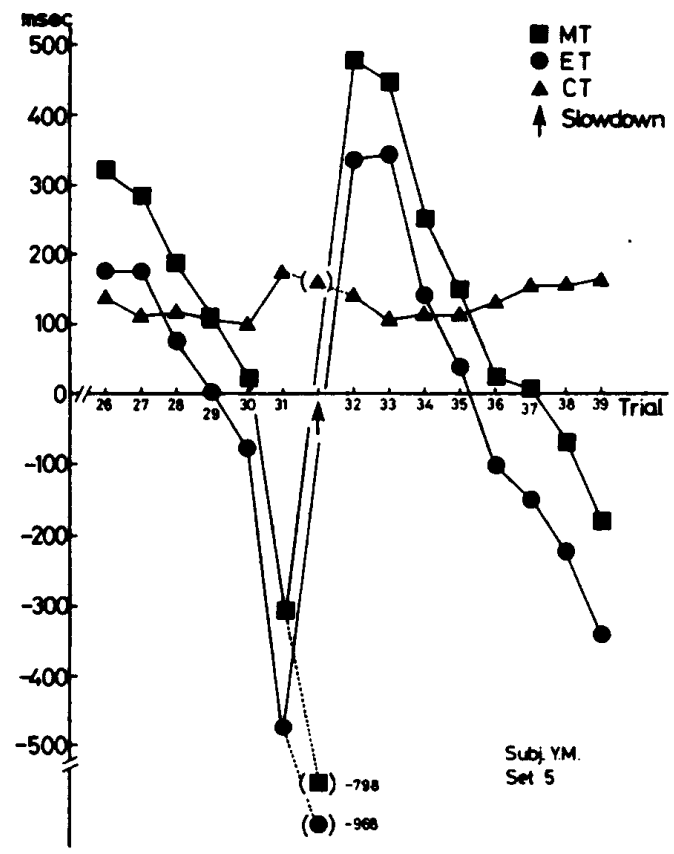

図 5 実耠伙括ける ET, MT, CT の一般的傾向

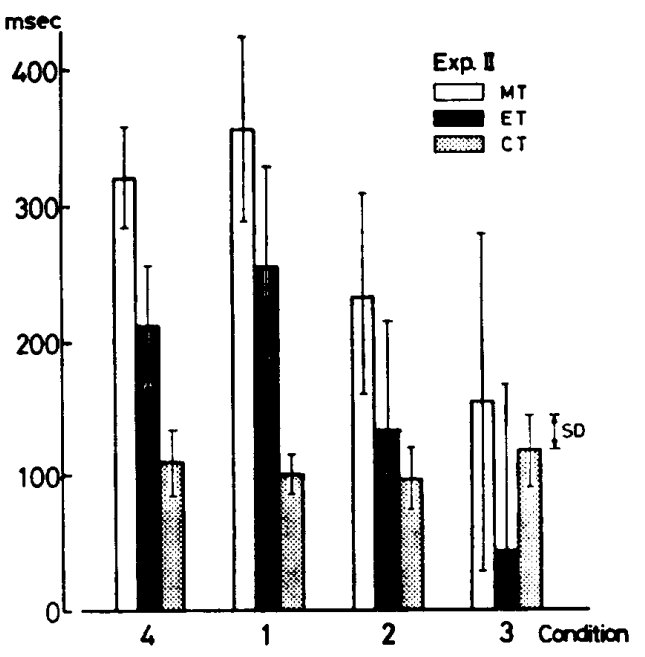

図 4 実験 II における各条件下での平均值

であり，刺激呈示の規則性から予想される予測に よる短縮が平均值にはみられなかった。これは方 向変化位置がランダムであったのと, 実際には移 動速度がかなり一定であったために，刺激呈示の 時間間隔にばらつきが生じたことが原因であると 考えられた。

そこでこの点を考虑して，実験 IIを行なった。

(3) 実験 Iに打ける連続方向变化条件での反忘時 間

図5に示したように，1セット内の ET 及び MT は㬰験 I と同様に試行が進むにつれて減少傾 向を示したが，その程度はさらに顕著で，ついに はマイナスの值を示す. 即ち, 刺激呈示よりも先 に反応を起こしてしま5ょ5な試行（図中の試行 30，31，36，37，38，39）が頻繁に現われた。そ して，个で示した，移動速度を急に低下させると い5予测崩壊刺敫に対して，先行する試行の反応 間隔と近似した間隔で反応が生じ（）で示した ように，極度な尚早反忘として現われる場合がし ばしばみられた。

また，停止に対しても，実験 I よりもさらに誤 反忘が多く，全停止数の $82.8 \%$ に生じた.

(4) 実験 Iににおける各条件下での反态時間とその 比較

困 4 に各条件下での平均値を示した。条件 3) に拈ける ET, MT は, 実験 I に比べて非常に小 さく, ET39.0msec, MT153msec であった。

条件 2) では, ET133msec, MT233msec と, 実験 I における条件 2) での值 (ET 123msec, 
MT 220msec) とほほ等しい值を示した。統計的 にもETに差はみられなかった $\left(\mathrm{F}_{(1.751)}=2.578\right.$, p>. 05).

条件 2）と3）の間の ET の差は有意であった （ET : $\mathrm{t}=9.89, \mathrm{p}<.05) か ゙, \mathrm{CT}$ は䄪 $100 \mathrm{msec}$ で有意差はみられなかった。

条件 1) の值は, ET $256 \mathrm{msec}$, MT $356 \mathrm{msec}$ と実験 I の值よりも大きくなり，条件 4）の值 (ET 212msec, MT 320msec) との間に有意な差 がみられなかった。これは，実験を暗室内で行 なったために心理学で言 5 目動運動が生じ20), 視 標の移動開始を弁別しにくかったことが原因であ ると考えられる。

条件 1) 及び 4) の CT は, 条件 2)や 3 ) と ほぼ等しく，100msec 前後の值を示した。

(5) 周期性の成立度と予測崩買刺激に対する誤反 応との関係

予測崩壊刺激插入時に出現する反応と周期性の 成立度との関係をみるために，図6に示したよ5 に, 実験 IIにおける予測崩壊刺激插入直前 3 試行 における筋放電と筋放電の時間間隔 $\left(\mathrm{I}_{1}, \mathrm{I}_{2}\right)$ を測 定し，その標準偏差をもって周期性の成立度を表 わすものとした。

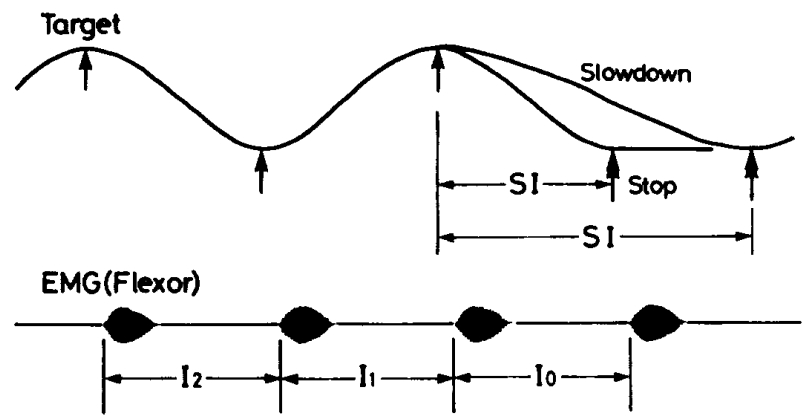

図 6 子測崩壊刺激捕入時の記録模式図

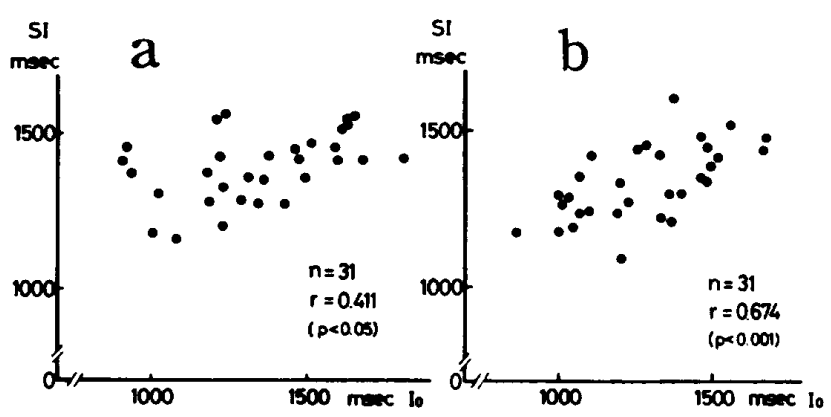

図 7 周期性成立度と予測崩壊刺激に対す る誤反応との関係 i）速度低下に対する反応について

標準偏差值を大小同数に分類し，各々の場合に ついて, 予测崩壊刺激 (速度低下) 插入時の刺激 呈示間隔 $(\mathrm{SI})$ と，筋放電開始時間 $\left(\mathrm{I}_{0}\right)$ との相 関をとり，図 7 (a 及び b) に示した。

標準偏差の小さい時（周期性の高い時; 平均 20.5msec）には図 7 a のよ5に低い相関を示し, 標準偏差の大きい時（周期性の低い時；平均 63.5 $\mathrm{msec})$ Kは図 $7 \mathrm{~b}$ のよ5に高い相関が得られた。

ii）停止挿入時の反応について

停止插入時に出現する反応の有無と周期性の成 立度との関係をみるために，停止㨂入時に反忘が 起こる場合と起こらない場合とで，この標準偏差 值に差があるかどらかを検討した，反応が起こる 場合は $88.7 \mathrm{msec}$ ，起こらない場合では $109.0 \mathrm{msec}$ であり，F検定を行なった結果，統計的に有意な 差は得られなかった $\left(F_{(1.89)}=3.69,0.05<p<\right.$ 0.10）が，停止に対して反応を起こす場合には標 準偏差も小さいという傾向がみられた。

2 ・眼球運動について

一般に, 眼球運動には smooth pursuit movement と saccadic movement があり，前者は視 対象の移動速度が遅い場合に発生し，追跡速度は およそ $30^{\circ} \sim 40^{\circ} /$ 秒が限度であるとされている4。

a
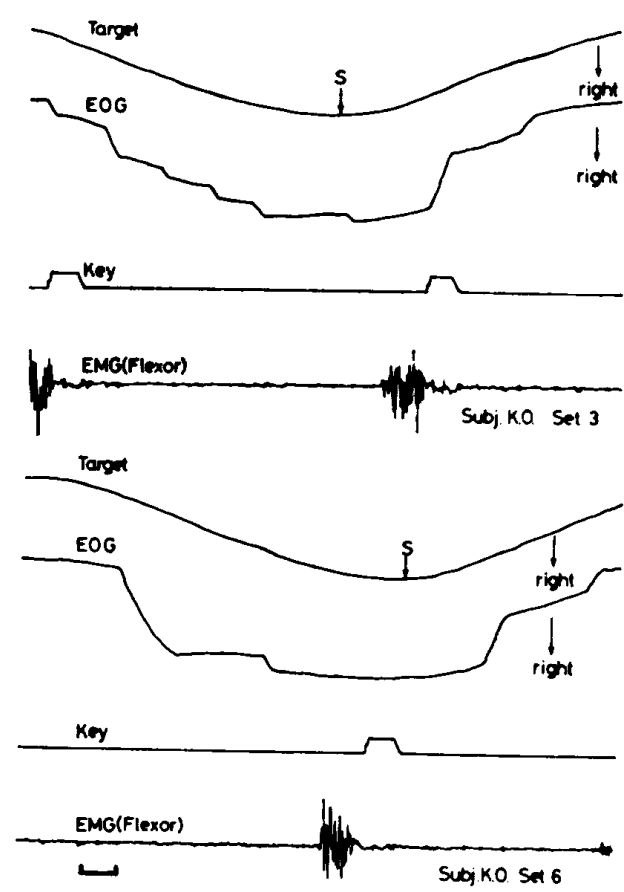

図 8 眼球運動の一般的パターン 左下の山は0.1秒を示す 
本実験の場合, 視標の移動平均速度が約 $80^{\circ} /$ 秒で あったのでほほとんどが saccadic movement で あった。その一例を図8（a 及びb）に示した。

図 $8 \mathrm{a}$ は予測が成立していない場合で, 眼球は saccade しつつ，遅れて視標の動きを追跡してい る.それに対し，予測が成立している場合の図 8 b では，眼球は視標よりも先に，方向変化すると 思われるあたりへ saccade し，刺激呈示を待つパ ターンを示している・連続方向変化条件では, 予 測崩壊刺激插入直後を除いて，ほとんどがこのパ ターンであった．剆定したEST（眼球待機時間） はこの方向変化待ち時間を示しており, 予測と眼 球運動との関係をみるために, EST と ETとの相 関係数を求め，表 1 に表わした。実験 I では， 5 人中 3 人までが有意な負の相関を示し，周期性の より確立した実験 II では，5人全員共に有意な負 の相関を示した。

表 1 眼球待㙨時間 (EST) と ET との相関係数

\begin{tabular}{c|c|c|c}
\hline & Subject & N & \multicolumn{1}{|c}{ r } \\
\hline \multirow{2}{*}{ E } & T. N. & 342 & $-0.321^{* * *}$ \\
X & R. I. & 409 & $-0.106^{*}$ \\
P & H. T. & 354 & $-0.002^{* * *}$ \\
I & Y. S. & 368 & $-0.216^{* * *}$ \\
& M. A. & 369 & $-0.006^{* * *}$ \\
\hline & H. T. & 363 & $-0.300^{* * *}$ \\
E & A. T. & 369 & $-0.326^{* * *}$ \\
X & K. O. & 371 & $-0.284^{* * *}$ \\
II & K. S. & 447 & $-0.214^{* * *}$ \\
& Y.M. & 349 & $-0.235^{* * *}$ \\
\hline
\end{tabular}

$* * * \mathrm{p}<.001 * * \mathrm{p}<0.01 * \mathrm{p}<.05$

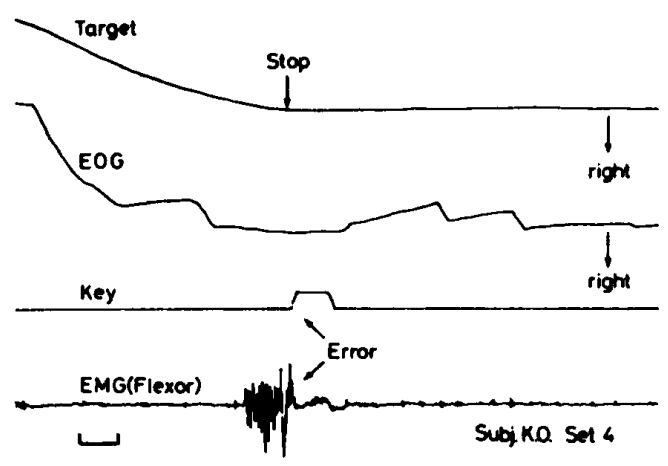

图 9 予測崩壊刺激 (停止) 挿入時の眼球運動 左下の山は0.1秒を示す.
また，図9のよ5に，予测崩壊刺激である停止 挿入時の眼球運動にもはっきりと予測の影響がみ られた．眼球は前もって saccade し，方向変化を 待つが，視標の停止と全く無関係に反芯方向へ saccade を開始し，視標を追跡しているかのよ5 に動く，その後，停止に気付き，視標の位置まで saccade して医り，視標を注視する。

このことは，眼球運動に関する指令が，視覚か らの入力情報とは全く独立に出されていることを 示すものである。

\section{IV.}

1 . 反忘時間について

反応時間に関する研究は，心理学において古く から行なわれており，研究論文も数多い。これら に颃いて，いわゆる反応時間 (reaction time:

RT) と呼ばれるすのは, 固定した光点の点滅とい 5刺激呈示から電鍵のスイッチが ONになるまで の経過時間として記録されたものがほとんどであ る.

しかし，本来，この時間は，刺激を受容して意 識によってこれを処理し，筋に運動指令を伝える までの時間（情報処理伝達時間）と，指令が筋に 伝わってから筋が収縮して箭力を発揮し, 内部抵 抗, 電鍵のハネネの弾性力, 慣性や摩擦等の身体の 外部抵抗を克服して要求された動作が発現するま での時間の二相に分けられる. 前者は純粋に神経 系の働きによって規定される時間であり，後者は 全く力学的に決定される時間である. 後者は外力 の大きさのみならず，被検者の筋力やパワーによ って大きく左在される。

筋力やパワーは，例えば男女間には大きな差が

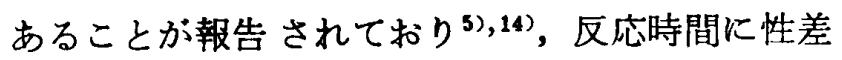
があるとい5従来の研究結果 ${ }^{2), 63,(19), 23)}$ は, この後 者の時間の差に起因しているすのと考えられる. この力学的な影響は全身を動かすような動作では さらに大きくなると考えられる。

従って, 反応時間の研究に際しては, 筋電困を 記録してこの 2 つの時間相を分離することが必要 であると思われる・筋電眓を記録して反応時間を 测定した Botwinick らは，反応時間を Premotor time（筋放電開始時間）と Motor time（筋 
収樎時間）に分離し，Premotor time に性差の無 いことを報告している8)。

また，筋電罒は記録していないが，猪飼らは， 刺激に対して跳躍するとい5 全身反応時間を湘定 し，筋への神経情報伝達時間を表わす動作開始時 間と，足先が離れるまでの筋収縮時間とを分離し ている ${ }^{9)}$ 。この方法による測定值をみると，筋収 縮時間には明らかに性差が認 められるのに対し， 動作開始時間には性差は見られない1。 また，山 川は，全身反応時間では，体重を持ち上げるだけ の筋力を必要とするので体重とい5負荷と筋力と の関係において性差を生ずるが，筋力をほとんど 必要としない動作を行なう場合の反応時間には, 性差はみられないことをあげ，「神経系の機能に は基本的に性差のないものと思われる」と述べて いる ${ }^{28)}$. 全身選択反応を調へた横山らの最近の研 究でも，その性差は筋力に上るものと考察されて いる ${ }^{29)}$.

これらのことからもわかるように，筋放電開始 時間には明確な性差が存在するとは考劣にくい。 本研究における被検者は女子のみであり，筋収縮 時間を含んだ反応時間 (MT) の值には, 男子に比 ベてCT の增大があるかもしれない。このこと を考慮して，本研究では主に，筋放電開始時間 (ET) について考察を加えることとした。

\section{2・動きに対する反㤁特性}

本実験では，移動視標を用いてその動きの変化 を刺激とする反応時間を測定し，結果として，動 きの变化を刺激とする方が 固定光刺激よりも反応 時間が小さいことが明らかとなった。

移動する視対象を用いた研究は，動体視力に関 するすのなどに多くみられるが，動きそのものに 対する反応時間に関する文献は非常に数少ない。 反応時間を測定した研究として，岩見ら ${ }^{11), 12), 18), ~}$

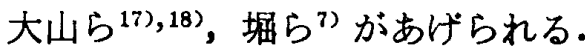

岩見ら，大山らは，動体視の場合には固定光刺 激の場合よりも反応時間が增加するとい5本実験 とは相反する結果を報告している。しかし，本実 験では，「視標の動きの変化」すなわち，停止し ていた視標が動き始めること（条件 1)）や移動方 向を変えること（条件 2 ) 及び 3 )）を刺激として いるのに対し，岩見ら，大山らの実験では，移動
中の「視標の輝度変化」を刺激としており, 視標 は動いてはいるものの，一定方向へ移動し続けて おり，刺激自体に大きな違いがみられる，我々。 予䧿実験において，消克ている視標のランプが移 動途中で点灯することを刺激とする反応時間を測 定したところ，岩見ら，大山らと同様な反応時間 の著しい增大がみられた。

このことから, 光の輝度変化やON, OFF に対 する反忘と動きの変化に対する反応とは，異った 生理的メカニズムに支配されており，人間は動き の変化に対してょり早く反応できる性質を持って いると言らことができるであろう。

また，堀らは，移動視標を用いる方が固定光刺 激よりも「反応速度が大きい(原著)」と述へてい るが7)，その実験方法は一定方向へ移動を続ける 視標の突然の消失を刺激としており，やはり，本 実験の才法とは異なっているので直接の比較は困 難である。

本実験における 4 種のどの条件下でも，CT の 值はほぼ等しく, 出力段階で費やされる時間は常 に一定と考㝋られるので, 刺激受容段階及び情報 処理段階において, 光刺激と動きの変化刺激との 差が生じるものであろ5と推测される．現在のと ころ, 大脳皮質視覚領における受容野では，静止 刺激よりも運動刺激によく反応し，運動方向や速 度に最適条件を持っていることが明らかにされて いる(15)ので，本契験から得られた結果は，このよ らな情報処理段階での時間の短縮によるものであ ると考党られる。

また, 動きを刺激とする場合, 結果 1-(3)でも述 ベたように，実験 I の如く，背沓が与えられる場 合と，奏験 II 如く，暗室中で，視標しか見えな い場合とでは，後者に錯覚によると思われる著し い反忘時間の増大がみられた。これは，視対象の 動きを認知する場合には，背景との対比が視線の 固定という意味で重要な役割りを果たしているこ とを物語るものであろう。

3 . 周期性と予測

連続方向変化条件において，1 時間の減少傾问や実験 IIで得られた平均值は，周 期性の成立によって 予測が成立することを示して いる.これは，固定光刺激を用いて行なった Oh- 
tsuki and Ishiwari ${ }^{18)}$ の結果と一致しており, 特に，本実験のよ5に「動きの変化」を刺激とす る場合には，反応時間の隇少傾向がより著しいよ 5に思われる。

また，挿入した予测崩壊刺激（停止及び速度低 下）に対しても反応を起こすという事実は，周期 性によって刺激呈示に対する予測が成立し，入力 信号とは全く無関係に運動指令が出されているこ とを裏付けるるのである。

塚原む，規則的なパルス入力を与艺て予測制御 させている際に，急に入力を止めると，入力が与 えられなくても手の方が動いて反応してしま5と い5，本実験の結果と一致する知見を報告してい $3^{211}$.

ところで，予測には，本来時間的予測と空間的 予測があると考えられる。本実験で言えば，前者 は刺激呈示間隔, 後者は方向変化位置に相当す る. 実験 ににおける条件は，この 2 つの要素を満 たしたものであって，刺激呈示に対する予測が最 も良く成立したものと言えるであろ5。ところ が，実験 Iでは空間的要素を規定していなかった にもかかわらず，結果にみられたよ5に予測が可 能であった。また，実験Iにおいて，速度低下の 予測崩壊刺激を挿入すると，速度が急に低下する ために，一定の時間を経ても，視標は方向変化位 置に到達していないにもかかわらず，反応が起き てしまい，極端な尚早反応として記録される場合 が数多くみられた。

これらのことから，少くとも本実験のように空 間的要素が一次元の場合，刺激呈示に対する予測 を成立させるには，空間的要素よりも時間的要素 の方が重要な役割りを果たしていると考えられ る.

その時間的要素を支配している周期性につい て，その成立度と予測崩壊刺激に対する譟反応と の関係を調へたところ，結果 1-(5)が示すよ5に， 周期性が成立している時ほど，停止に対する誤反 态が起こりやすく，また，速度低下の予測崩買刺 激に対して，先行する試行の反応間隔と近似した 一定の時間間隔で反応が生じていることがわか る.

このことから，周期性を持つ刺激に対して反応
し続ける5ちに，刺激の周期性が無意識の5ちに 個人の内部にとり入れられ，その内的に確立した 周期性，すなわち，刺激の予測に基いて，現実の 刺激とは無関係に反応動作が発現してしま5よ5 になる。言い换えれば，無意識の5ちに出力が入 力とは無関係にフィードフォワード制御されるよ うになってゆくことが明らかである。

動きと予測の関係については，緒言にも述へた ように,「タイミング」という観点から多くの研 究がなされている. 中でも山田らはタイミングコ ントロールに関する一連の研究において，予測さ れる現象にいかに5まくタイミングを合わせられ るかという能力をタイミング誤差時問を用いて検 討している23),24),25’,23!，27).

彼らは視標に対する動作の時關的適合をタイミ ングと定義し23)，その適合点をタイミングポイン トと呼んでいる241，彼らの用語を借りれば，本実 験の結果は, 刺激呈示時点（これがタイミングポ イントに相当する）の予測によって反応動作がタ イミング動作に近ついてゆくと言うことができよ 5 .

しかしながら，本実験はあくまでも事態の変化 に対する「反応」の早さに着目していること, 及 び, 同じ予測であっても, 山田らの如く, 積極的 な自由意志によって成立する予測ではなく，無意 識のうちに成立してしま5予湘であること，など の点でタイミングに関する研究とは視点を異にす るものである.

\section{4. 眼球運動に関して}

連続方向変化条件において, 眼球は刺激が発生 すると思われるあたりへ先に saccade し，刺激呈 示を待つとい5パターンを示し, 眼球待機時間 (EST) と ET との間に有意な目の相関が得られ た.これは, 眼球が視標よりも早目に saccade し た時にはET は小さくなることを意味しており， 刺激の周期性によって刺激呈示に対する予测が成 立すると，眼球もまた予測の影響を受けることを 示すものである.

渡部は正弦波を用いて視標を動かし，眼球運動 を記録したところ，位相遅れがかなり小さく，と もすれば，入力信号よりも進位相となるとい5眼 球の予測機能について報告している ${ }^{22)}$.これは本 
実験の結果と軌を一にするるのである.

これらのことを考えあわせると，入力 $\rightarrow$ 処理 $\rightarrow$ 出力とい5反応経路の5ち, 出力だけが予測制御 されるのではなく，眼球とい5受容器自体すすで に予測の影響を受け，刺邀をより速やかに受容し よ5とする衔きを持っていると考えられる。ま た，停止㨂入時に現われた，行きすぎ・修正眼球 運動は, 眼球自体が入力信号とは全く独立に制御 されていることを示唆するすのであり，眼球が行 きすきたという情報を出力のコピーと視覚から返 ってきたフィードバックとの mismatchによって 得, 誤まった出力を修正したものと考えられるで あろ5。

以上のよ5に，人間は，刺激発生に対する予測 が成立するよ5な条件下においては，遅れのない 反応を可能にするような効果器のフィードフォワ 一ド制御機構とともに，眼球運動にもみられるよ $5 に$ ，外界の変化に関する情報をより速やかに受 容しよ5とする受容器のプリセット機構を働かせ ることによって，入力から出力に至る反㤁経路全 体を円滑化し，動作を能率化するようにできてい ると言らことができる。

\section{$\mathrm{V}$. 要}

的

移動視標を用い，周期的な方向变化を刺激とし て反㤁時間を測定することにより，動きに対する 反忘と，その予测との関連についての検討を行な った。 その結果，次のようなことが明らかになっ た.

（1）動きを刺激とする反応の方が，固定光刺激に 対する反応よりも早い。

(2) 周期的に刺激が与えられると，刺激発生に対 する予测が成立し，遅れのない反忍が可能とな る.

(3) 予測が成立している際には，入力には関係な く出力が形成されるので，予測を裏切るよ5な刺 激を㨂入すると，誤反応を生じる場合が多くみら れる。

(4) 刺激呈示点に対する予測について, 空間的予 测よりも時間的予測の方がより重要な役割を果た している。

(5) 予測が成立している場合には，眼球は刺激が
呈示されると思われる位置へ，視標よりも先に saccade して，刺激が与えられるのを待つとい5 特有のパターンを示す。

\section{引用 文 献}

1）浅見高明，芝山秀太郎，丹羽昇「全身反応時間の 測定法とその応用」体育学研究，7-1:143，1962.

2) Botwinick, J. and J.F. Brinley, "An Analysis of Set in Relation to Reaction Time," J. Exp. Psychol., 63 : 568-74, 1962.

3) Botwinick, J. and L.W. Thompson, "Premotor and Motor Components of Reaction Time," J. Exp. Psychol., $71:$ 9-15, 1966.

4) Dodge, R., R.C. Travis and J.C. Fox, "Optic Nystagmus III. Characteristics of the Slow Phase," Arch. Neurol., Chicago, 24:21-24, 1930. in H.T.A. Whiting ( $\epsilon$ d.), Readings in Sports Psychology, Henry Kimpton Publishers: London 1972.

5 ）福永哲夫, ヒトの䋓対筋力, 杏林書院, 1978. pp. $75-105$.

6) Henry, F.M., "Influence of Motor and Sensory Sets on Reaction Latency and Speed of Discrete Movements," Res. Quart., 31 : 459—68, 1960.

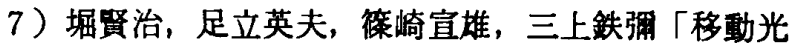
点による反応時の分析」体力科学，6:100-03， 1956.

8 ）猪飼道夫「動作に先行する抑制機構」日本生理学 雑誌, $17: 292-98,1955$.

9 ）猪飼道夫，浅見高明，芝山秀太郎「全身反応時間 の測定とその応用」Olympia，7:18-27，1961.

10) 岩原信九郎, 教育と心理のための推計学, 第22版, 日本文化科学社, 1979. pp. 292-94.

11）岩見恒典，寺田邦昭，山田久恒，森田修朗「動体 視反心時間飞関する研究(1)」体育学研究， 11-5： $73,1967$.

12）岩見恒典，寺田邦昭，山田久恒，森田修朗「動体 視反応時間に関する研究(2)」体育学研究， 12-5 : 154,1968

13）岩見恒典，寺田邦昭，山田久恒，森田修朗「動体 視反応時間に関する研究(3)」体育学研究， $13-5$ : $89,1969$.

14）金子公有，睛発的パワーからみた人体筋のダイナ ミクス, 杏林書院, 1974. pp. 82-92.

15) Marg, E., J.E. Adams and B. Butkin, "Recep- 
tive Fields of Cell in the Human Visual Cortex," Experientia, $24: 348-50,1968$.

16) Ohtsuki, T. and M. Ishiwari, "Dead Time" in Reaction to Unexpected Changes of Situation with Reference to "Feinting Skill.", in E. Asmussen and $\mathrm{K}$. J $\phi$ rgensen (eds.), Biomechanics VI-A, University Park Press: Baltimore, 1977. pp. $165-71$.

17）大山慈德, 山田久恒, 石垣尚男「動体周辺視反忘 時間汇関する研究 I」日本体育学会第28回大会号, 1977, p. 175.

18）大山慈德, 山田久恒, 石坦尚男「動体周辺視反応 時間任関する研究 II 日本体育学会第30回大会号, 1979 , p. 168.

19）斎藤松雄,「視媤覚刺激に対する運動能力の研究」 体力科学, $9: 406-13,1960$.

20）椎名健, 「運動の知觉, 自動運動」, 和田陽平, 大 山正, 今井省吾(編)，感覚知覚心理学ハンドブック， 誠信書局, 1968. pp. 655-57.

21）塚原進,「人の動作に招けるフィードバックとフィ ードフォワード」, 真島英信, 猪飼道夫(編), 生体 の運動㙨構とその制御, 杏林書院, 1972. pp.231一 51.

22）渡部煋「眼球運動の制御機構」NHK技術研究, $18: 20-42,1966$.
23）山田久恒「タイミングコントロールに関する研究 一視機能がタイミング動作に及ほす影整について一! 体育学研究, 9:91-96, 1966.

24）山田久恒, 岩見恒典, 寺田邦昭「タイミングコン トロールK関する研究（視機能がタイミング動作に 及ほす影理に関する研究……第 3 報)」体育学:研究, $11: 94-100,1966$.

25）山田久恒，岩見恒典，寺田邦昭，森田修朗「タイ ミングコントロールに関する研究一視機能がタイミ ング動作に及ほす影貔について, 第 4 報一」体育学 研究, $11: 190-95,1966$.

26）山田久恒, 山田知通, 岩見恒典, 寺田邦昭, 森田 修朗「タイミングコントロールに関する研究（見越 反応的タイミング動作について)」体育学研究, 16 : 137-44, 1971.

27）山田久恒, 寺田邦昭, 石垣尚男, 大山意德「反復 連続タイミング動作におけるタイミング誤差時間に

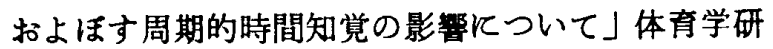
究, 3:145-53, 1976.

28）山川純,「skill の性差」，石河利寛，松井秀治(編), スポーツ医学, 第 6 版, 杏林畵院, 1978. pp.17375.

29）横山泰行，湯浅達郎「移動距雔と空間方向を同時 に考虑した全身選択反応時間」体育学研究, 24 : 109-16, 1979. 